\title{
Evaluation of Nitrate Removal from Water Using Activated Carbon and Clinoptilolite by Adsorption Method
}

\author{
Morteza Kashefi Asl ${ }^{1}$, Amir Hesam Hasani ${ }^{2}$ and Ehasn Naserkhaki ${ }^{3 *}$ \\ ${ }^{1}$ School of Marine Science and Technology, Islamic Azad University, North Tehran Branch, Tehran, Iran. \\ ${ }^{2}$ Faculty of Environmental, Islamic Azad University, Science and Research Branch, Tehran, Iran. \\ ${ }^{3}$ Graduate Student in Chemical Engineering, Environmental Engineering, Islamic Azad University, \\ North Tehran Branch, Tehran, Iran.
}

http://dx.doi.org/10.13005/bbra/2131

(Received: 02 February 2016; accepted: 04 April 2016)

\begin{abstract}
Nitrate is colorless, odorless and has no taste and is not detectable in drinking water without testing. Nitrate is one of the most important pollutants of urban and rural drinking water. Recently, the use of different technologies to remove these contaminants is investigated. In this study, activated carbon and natural zeolite clinoptilolite are used as two adsorpents for the removal of nitrate from the water by adsorption in different situations. Results of removing these two adsorbents by batch method and changing effective factors such as contact time, temperature, $\mathrm{pH}$, adsorbent dosage and initial concentration of the Nitrate. The best efficiency for nitrate removal from $60 \mathrm{ml}$ water for activated carbon in a $4 \mathrm{~g}$ dose sorbent, contact time of $60 \mathrm{~min}$, temperature of ${ }^{\circ} \mathrm{c} 20$, $\mathrm{pH}=6.5$ and the initial concentration of $100 \mathrm{mg} / \mathrm{lit}$ is 62.61 percent and from adsorpent Clinoptilolite, in terms of $4 \mathrm{~g}$ adsorbent dosage, contact time of $60 \mathrm{~min}$, temperature of ${ }^{\circ} \mathrm{c}$ $20, \mathrm{pH}=5.5$ and the initial concentration of $100 \mathrm{mg} / \mathrm{lit}$ is 8.7 percent. Freundlich adsorption isotherm for activated carbon and Langmuir adsorption isotherm have good match for clinoptilolite. Second order pseudo adsorbing kinetics (Ho) for activated carbon and first order pseudo adsorbing kinetics (Lagergren) are in good agreement for clinoptilolite. From the obtained adsorbing kinetics, we can conclude that Nitrate adsorbing from the water using chemical activated carbon and physical clinoptilolite are used.
\end{abstract}

Key words: Nitrate, Water, Activated carbon, Clinoptilolite, Adsorption, Adsorption Isotherms, Adsorption Kinetics

Nitrate is a polyatomic ion whose molecular formula is $\mathrm{NO}\{f$ and its molecular mass is 62.0049 grams per mole. This ion is derived from nitric acid ${ }^{15}$. Nitrate ions such as ammonium ions are not attached to soil particles, so moves along water movement in soil and enter groundwater and surface waters.

Wide industrial activities, agriculture and services activities such as untreated waste water disposal into the environment, the indiscriminate use of chemical and animal fertilizers in agriculture

\footnotetext{
* To whom all correspondence should be addressed. E-mail: ENK7770@gmail.co
}

make entrance of different combinations particularly nitrate ion to water resources (surface and underground). Nitrates in surface water are seen with small amounts, but found in groundwater at higher levels.

Water quality standard for humans is usually based on the protection of children's health. United States of America Environmental Protection Agency (EPA) has announced the maximum allowable concentration of nitrate in drinking water as $10 \mathrm{mg} / \mathrm{lit}$ based nitrogen ${ }^{18}$. According to the National Standard 1053 of Institute of Standards and Industrial Research of Iran (ISIRI), allowable amount of nitrate in water has been set $50 \mathrm{mg} / \mathrm{lit}^{16}$. 
In this study, the initial concentration of nitrate solution in all samples exceeds the limit of $50 \mathrm{mg} /$ lit. Nitrates alone do not make disease, but all the dangers of nitrates for health are related to its conversion to nitrite. Side effects of high nitrates cause harmfulness to health as two forms to the body.

Complications of methemoglobinemia or blue baby syndrome are created in infants and young children by consumption of water contaminated with nitrates ${ }^{2}$. In addition the possibility of carcinogenic water contaminated with nitrate has also been reported. Nitrosamine is a compound that is formed also in environments containing high nitrate and are known as carcinogens matters.

These compounds are one of the causes of gastrointestinal cancer particularly gastric cancer in humans ${ }^{8}$.

There are different ways to remove nitrate from drinking water, including the physical, chemical and biological methods some of which are not practical on a large scale.

The most common methods to reduce nitrates in large scale include:

Dilution, ion exchange and $\mathrm{RO}^{3}$ and some of the methods in laboratory scale for nitrate removal include:

Biological method ${ }^{11}$, electrochemical method $^{6}$ and adsorption methods ${ }^{5}$. In this study, we examined the nitrate removal from water using adsorption method.

The aim of this study was to evaluate nitrate removal from water using two activated carbon adsorbent and clinoptilolite in different situations and comparing the two adsorbent together and get the best possible condition for the removal of nitrates from water more.

\section{Adsorption process}

In adsorption process, transferring a component is from the gas or liquid to a solid phase. ${ }^{13,4}$ generally due to very easy design, ease of operation, comfortable repair and maintenance and progress of construction technologies of adsorbents with high capacity is considered as the best method for water treatment process.

The remarkable thing is that to achieve optimal removal rate, choosing a suitable adsorbent to remove nitrate is very important. Conventional and non-conventional materials based on a variety of different bases are designated for nitrate removal from water. In the process of adsorption, consumer absorbent price is the most important economic factor in the process, so most researchers try to build a low-cost adsorbent in the process ${ }^{5}$.

\section{METHODSAND MATERIALS}

\section{Adsorbents used}

Two adsorbents of clinoptilolite and activated carbon were used in this study. Because the goal is comparison of the two adsorbent together, so we try to choose the grain size of two adsorbents in a range.

Clinoptilolite adsorbent used in this study was prepared by "Afrazand” company. 1 to $3 \mathrm{~mm}$ grain size was used as granules. The results of elemental analysis of zeolite are as follows: [14]

\begin{tabular}{cccccccc} 
Elements & $\mathrm{Fe}_{2} \mathrm{O}_{3}$ & $\mathrm{CaO}$ & $\mathrm{K}_{2} \mathrm{O}$ & $\mathrm{Na}_{2} \mathrm{O}_{3}$ & $\mathrm{Al}_{2} \mathrm{O}_{3}$ & $\mathrm{SiO}_{2}$ & L.O.I * \\
\hline Percentage & $0.2-0.9$ & 0.6 & 4.4 & 3.8 & 11 & 68.5 & 12-Oct \\
\hline
\end{tabular}

*. loss on ignition

To use this adsorbent, first it should be washed several times with distilled water to wash away the pollution and then put in the oven with temperature of $c^{\circ} 105$ for 24 hours and then put in desiccator for 72 hours and use for testing.

The adsorbent activated carbon used in this study was made by SigmaAldrich manufacturing company with product code C2889. ${ }^{17}$ The activated carbon used in the aggregation (8-20 mesh) was 0.85-2.4 mm and used as a bulk mode granules.

\section{Preparation of solutions:}

All experiments of the study were conducted in the laboratory of Department of Chemistry, Islamic Azad University in North Tehran. For preparation of standard solution of nitrate, sodium nitrate $\left(\mathrm{NaNO}_{3}\right)$ product from Merck Company in Germany was used. For this, in order to prepare a nitrate mother solution with concentrations of $1000 \mathrm{mg} / \mathrm{lit}, 1.37 \mathrm{~g}$ Sodium Nitrate reached to $1000 \mathrm{ml}$ size. To maximize volume, the 
Distilled water produced in the lab was used. To adjust the $\mathrm{pH}$ of nitrate solution, 1 and 0.01 normal $\mathrm{HCl}$ and 1 and 0.01 normal $\mathrm{NaOH}$ were used.

\section{Adsorption isotherms study}

The relationship between the amount of adsorbed substance (q) and the concentration of the substance in liquid phase (c) at temperatures $\mathrm{T}$ is adsorption isotherm [13, 4]. The most popular theories to explain the adsorption process that had been expressed include:

- Langmuir_equation

- Freundlich_equation

In order to determine the adsorption isotherms, Langmuir and Freundlich isotherm models linear forms were used to analyze nitrate adsorption.

Linear form of Langmuir model is stated using the following equation: [10]

$$
\frac{1}{q_{e}}=\frac{1}{C_{e} k_{1} q_{\max }}+\frac{1}{q_{\max }}
$$

In this equation, $\mathrm{q}_{\mathrm{e}}$ is adsorbed nitrate per unit mass of adsorbent in terms of milligrams per gram $(\mathrm{mg} / \mathrm{g})$ and can be obtained from the following equation.

$$
q_{e}=\frac{C_{i}-C_{e}}{m} \times V
$$

Where Ci is initial nitrate concentration in milligrams per liter, $\mathrm{m}$ is adsorbent weight in grams and $\mathrm{v}$ is the volume of solution in liters. $\mathrm{C}_{\mathrm{e}}$ is equilibrium concentration of adsorbed material in solution phase after adsorption in terms of milligrams per liter and $\mathrm{k}_{1}$ and $\mathrm{q}_{\max }$ are the Langmuir constants obtained by plot $\frac{1}{q_{\theta}}$ versus $\frac{1}{C_{e}}$. This will be achieved by drawing a straight line curve whose slope is $\frac{1}{k_{1} q_{\max }}$ and intercept is $\frac{1}{q_{\max }}$.

Linear form of Freundlich equation can be expressed using the following equation. [9]

$$
\log q_{e}=\log k_{2}+\frac{1}{n} \log C_{e}
$$

In this equation, $\mathrm{q}_{\mathrm{e}}$ is capacity to absorb at the equilibrium in terms of milligrams per liter, $C_{e}$ is absorbed matter equilibrium concentration in terms of milligrams per liter and $\mathrm{K}_{2}$ and $\mathrm{n}$ are Freundlich constants obtained by plot $\log q_{e}$ versus $\log \mathrm{C}_{\mathrm{e}}$. Obtained by plot versus, straight line with a slope of and intercept of $\log k_{2}$ is obtained.

\section{Adsorption kinetics}

One of the most important factors for adsorption system design (to determine residence time of absorbing material and dimensions of the reactor) is the forecasting quickness of adsorption process controlled by the system kinetics. Adsorption kinetics depends on the physical and chemical properties of the sorbent that affect absorption mechanism and using adsorption kinetics, we can understand physical or chemical adsorptions.

To investigate the mechanisms of absorption, adsorption constants can be calculated using Equation Lagergren, first order pseudo mechanism and $\mathrm{HO}$ equation second order pseudo mechanism. Linear form of first order pseudo mechanism equation is as follows: [7]

$$
\operatorname{Ln}\left(\mathrm{q}_{\mathrm{e}}-\mathrm{q}_{\mathrm{t}}\right)=-\mathrm{k}_{1} \mathrm{t}+\operatorname{Ln} \mathrm{q}_{\mathrm{e}}
$$

According to this equation, in the case of drawing changes of versus time, a straight line is obtained that the slope is - $\mathrm{k}$ and the its intercept is .

In equivalents above, $\mathrm{q}_{\mathrm{e}}, \mathrm{q}_{\mathrm{t}}$ and $\mathrm{k}_{1}$ are equilibrium adsorption capacity (nitrate adsorbed on the adsorbent at the time of equilibrium) (in $\mathrm{mg} /$ g), adsorption capacity at the time t (the amount of ions adsorbed on the adsorbent at time $t$ ) (in terms of $\mathrm{mg} / \mathrm{g}$ ) and a fixed rate of Lagergren adsorption (in terms of $1 / \mathrm{min}$ ), respectively. Also, linear form of second order pseudo mechanism equation can be written as follows: [12]

$$
\left(\frac{\mathrm{t}}{\mathrm{q}_{\mathrm{t}}}\right)=\frac{1}{\mathrm{k}_{2} \mathrm{q}_{\mathrm{e}}{ }^{2}}+\left(\frac{1}{\mathrm{q}_{\mathrm{e}}}\right) t
$$

According to recent equation, the relationship between and time is linear whose slope is and its intercept is in which these coefficients are obtained by drawing variations of against the time.

In these equations, $\mathrm{q}_{\mathrm{e}}, \mathrm{q}_{\mathrm{t}}$ and $\mathrm{k}_{2}$ are equilibrium adsorption capacity (in $\mathrm{mg} / \mathrm{g}$ ), adsorption capacity at the time $\mathrm{t}$ (in terms of $\mathrm{mg} / \mathrm{g}$ ) and the reaction rate constant of $\mathrm{Ho}$ et al. (adsorption constant in Ho model in terms of (g)/ (mg.min)), respectively.

\section{Nitrate removal process}

In this study, adsorption tests were done 
by batch method into $100 \mathrm{~m}$ Erlenmeyer flask and $60 \mathrm{ml}$ nitrate solution volume on the electric heating magnetic stirrer with $250 \mathrm{rpm}$. To conduct experiments in discrete conditions, various parameters such as contact time, temperature, $\mathrm{pH}$, adsorbent dosage and initial concentration of nitrate were investigated.

In all studies, various parameters except initial concentration of nitrate solution, the initial concentration of $100 \mathrm{mg} /$ lit nitrate were used. All tests were repeated three times and average of them was reported in this paper.

Table 1. Values of contact time effect on the efficiency of nitrate removal

\begin{tabular}{|c|c|c|c|c|c|}
\hline \multicolumn{3}{|c|}{ Clinoptilolite } & \multicolumn{3}{|c|}{ Activated carbon } \\
\hline $\begin{array}{l}\text { Contact } \\
\text { time (min) }\end{array}$ & $\begin{array}{l}\text { Removal } \\
\text { efficiency }\end{array}$ & $\begin{array}{l}\text { The Remaining } \\
\text { concentration }\end{array}$ & $\begin{array}{l}\text { Contact } \\
\text { time (min) }\end{array}$ & $\begin{array}{l}\text { Removal } \\
\text { efficiency }\end{array}$ & $\begin{array}{l}\text { The remaining } \\
\text { concentration }\end{array}$ \\
\hline 45 & 2.98 & 97.02 & 45 & 53.14 & 46.86 \\
\hline 60 & 8.7 & 91.3 & 60 & 57.77 & 42.23 \\
\hline 75 & 10.66 & 89.34 & 75 & 58.89 & 41.11 \\
\hline 90 & 11.05 & 88.95 & 90 & 59.32 & 40.68 \\
\hline 105 & 11.37 & 88.63 & 105 & 59.73 & 40.27 \\
\hline 120 & 11.45 & 88.55 & 120 & 60.12 & 39.88 \\
\hline
\end{tabular}

Table 2. Values of Temperature effect on the efficiency of nitrate removal

\begin{tabular}{|c|c|c|c|c|c|}
\hline \multicolumn{3}{|c|}{ Clinoptilolite } & \multicolumn{3}{|c|}{ Activated carbon } \\
\hline $\begin{array}{l}\text { Contact } \\
\text { time (min) }\end{array}$ & $\begin{array}{l}\text { Removal } \\
\text { efficiency }\end{array}$ & $\begin{array}{l}\text { The Remaining } \\
\text { concentration }\end{array}$ & $\begin{array}{l}\text { Contact } \\
\text { time (min) }\end{array}$ & $\begin{array}{l}\text { Removal } \\
\text { efficiency }\end{array}$ & $\begin{array}{l}\text { The remaining } \\
\text { concentration }\end{array}$ \\
\hline 20 & 8.7 & 91.3 & 20 & 57.77 & 42.23 \\
\hline 30 & 5.43 & 94.57 & 30 & 53.16 & 46.84 \\
\hline 40 & 3.74 & 96.26 & 40 & 45.95 & 54.05 \\
\hline 50 & 2.31 & 97.69 & 50 & 36.88 & 63.12 \\
\hline
\end{tabular}

Table 3. Values of pH effect on the efficiency of nitrate removal

\begin{tabular}{lccccccc}
\hline & Clinoptilolite & & & \multicolumn{3}{c}{ Activated carbon } \\
\cline { 1 - 2 } $\begin{array}{l}\text { Contact } \\
\text { time (min) }\end{array}$ & $\begin{array}{c}\text { Removal } \\
\text { efficiency }\end{array}$ & $\begin{array}{c}\text { The Remaining } \\
\text { concentration }\end{array}$ & & $\begin{array}{c}\text { Contact } \\
\text { time (min) }\end{array}$ & $\begin{array}{c}\text { Removal } \\
\text { efficiency }\end{array}$ & $\begin{array}{c}\text { The remaining } \\
\text { concentration }\end{array}$ \\
\hline 5.5 & 8.7 & 91.3 & & 5.5 & 5.5 & 57.77 & 42.23 \\
6.5 & 3.68 & 96.32 & & 6.5 & 62.61 & 37.39 \\
7.5 & 2.18 & 97.82 & & 7.5 & 61.05 & 38.95 \\
8.5 & 1.22 & 98.78 & & 8.5 & 60.12 & 39.88 \\
\hline
\end{tabular}

Table 4. Values of adsorbent dosage effect on the efficiency of nitrate removal

\begin{tabular}{lcccccc}
\hline & Clinoptilolite & & & 3 & Clinoptilolite \\
\cline { 1 - 2 } $\begin{array}{l}\text { Clinoptilolite } \\
\text { dosage }\end{array}$ & $\begin{array}{c}\text { Removal } \\
\text { efficiency }\end{array}$ & $\begin{array}{c}\text { The Remaining } \\
\text { concentration }\end{array}$ & $\begin{array}{c}\text { Activated carbon } \\
\text { dosage }\end{array}$ & $\begin{array}{c}\text { Removal } \\
\text { efficiency }\end{array}$ & $\begin{array}{c}\text { The remaining } \\
\text { concentration }\end{array}$ \\
\hline 1 & 3.23 & 96.77 & 1 & 30.07 & 69.93 \\
2 & 4.75 & 95.25 & & 2 & 42.14 & 57.86 \\
3 & 6.68 & 93.32 & & 3 & 54.62 & 45.38 \\
4 & 8.7 & 91.3 & 4 & 62.61 & 37.39 \\
\hline
\end{tabular}


After each test, for both adsorbents, solution is passed from Whatman 42 filter paper to separate adsorbing particles from the solution, then concentration of nitrate in the filtrate by UV spectrophotometer, at $220 \mathrm{~nm}$ by spectrophotometer UV/Vis is read ${ }^{1}$.

The lab investigates effects of different factors with measured change factor and other

Table 5. Values of Initial nitrate concentration effect on the efficiency of nitrate removal

\begin{tabular}{|c|c|c|c|c|c|}
\hline \multicolumn{3}{|c|}{ Clinoptilolite } & \multicolumn{3}{|c|}{ Activated carbon } \\
\hline Initial nitrate & Removal & The Remaining & Initial nitrate & Removal & The remaining \\
\hline concentration $\left(\frac{\mathrm{mg}}{\text { lit }}\right)$ & efficiency & concentration & concentration & efficiency & concentration \\
\hline 50 & 3.69 & 48.15 & 50 & 76.09 & 11.95 \\
\hline 75 & 5.9 & 70.57 & 75 & 70.59 & 22.05 \\
\hline 100 & 8.7 & 91.3 & 100 & 62.61 & 37.4 \\
\hline 125 & 27.64 & 90.45 & 125 & 61.93 & 47.58 \\
\hline 150 & 36.87 & 94.69 & 150 & 61.75 & 57.37 \\
\hline 175 & 43.76 & 98.42 & 175 & 61.54 & 67.30 \\
\hline
\end{tabular}

Table 6. Values and constants of the first and second pseudo-models for activated carbon adsorbent

\begin{tabular}{|c|c|c|c|c|c|}
\hline \multicolumn{3}{|c|}{ First order pseudo kinetic model } & \multicolumn{3}{|c|}{ Second order pseudo kinetic model } \\
\hline$q_{e}$ & $\mathrm{~K}_{1}$ & $\mathrm{R}^{2}$ & $\mathrm{q}_{\mathrm{e}}$ & $\mathrm{K}_{2}$ & $\mathrm{R}^{2}$ \\
\hline 1.354 & 0.061 & 0.985 & $\begin{array}{l}0.978 \\
\left(\frac{\mathrm{mg}}{m}\right)\end{array}$ & 0.115 & 0.998 \\
\hline
\end{tabular}

Table 7. values and constants of the first and second pseudo-models for Clinoptilolite adsorbent

\begin{tabular}{cccccccc}
\hline \multicolumn{2}{l}{ First order pseudo kinetic model } & & \multicolumn{3}{c}{ Second order pseudo kinetic model } \\
\cline { 1 - 4 } \cline { 5 - 7 } $\mathrm{q}_{\mathrm{e}}$ & $\mathrm{K}_{1}$ & $\mathrm{R}^{2}$ & & $\mathrm{q}_{\mathrm{e}}$ & $\mathrm{K}_{2}$ & $\mathrm{R}^{2}$ \\
\hline 3.36 & 0.074 & 0.991 & & -0.214 & 0.022 & 0.239 \\
\hline
\end{tabular}

Table 8. Values and constants of Langmuir and

Freundlich isotherms for activated carbon adsorbent

\begin{tabular}{cccccccc}
\hline & \multicolumn{3}{c}{ Langmuir model } & & & \multicolumn{3}{c}{ Freundlich model } \\
\cline { 1 - 4 } \cline { 5 - 7 } $\mathrm{k}_{1}$ & $\mathrm{q}_{\max }$ & $\mathrm{R}^{2}$ & & $\mathrm{k}_{2}$ & $\mathrm{n}$ & $\mathrm{R}^{2}$ \\
\hline-108.41 & 0.542 & 0.934 & & 0.110 & 1.663 & 0.968 \\
\hline
\end{tabular}

Table 9. Values and constants of Langmuir and Freundlich isotherms for Clinoptilolite adsorbent

\begin{tabular}{ccccccc}
\hline \multicolumn{3}{c}{ Langmuir model } & & & \multicolumn{3}{c}{ Freundlich model } \\
\cline { 1 - 3 } \cline { 5 - 7 } $\mathrm{k}_{1}$ & $\mathrm{q}_{\max }$ & $\mathrm{R}^{2}$ & & $\mathrm{k}_{2}$ & $\mathrm{n}$ & $\mathrm{R}^{2}$ \\
\hline-0.0097 & -0.0308 & 0.976 & & $1.745 \mathrm{E}-10$ & 0.209 & 0.768 \\
\hline
\end{tabular}




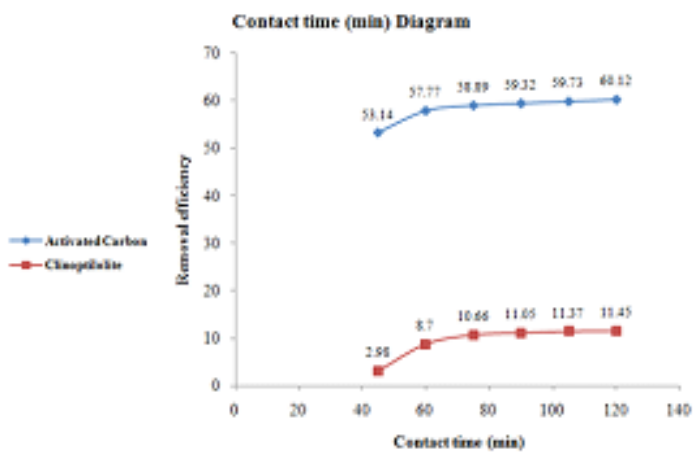

$\left(\mathrm{V}=60 \mathrm{ml}\right.$, Adsorbent dosage $=4$ grams, $\mathrm{T}=20^{\circ} \mathrm{c}, \mathrm{pH}=5.5$ , The initial concentration $=100 \mathrm{mg} / \mathrm{lit}$ )

Fig. 1. Effect of contact time on the nitrate removal efficiency

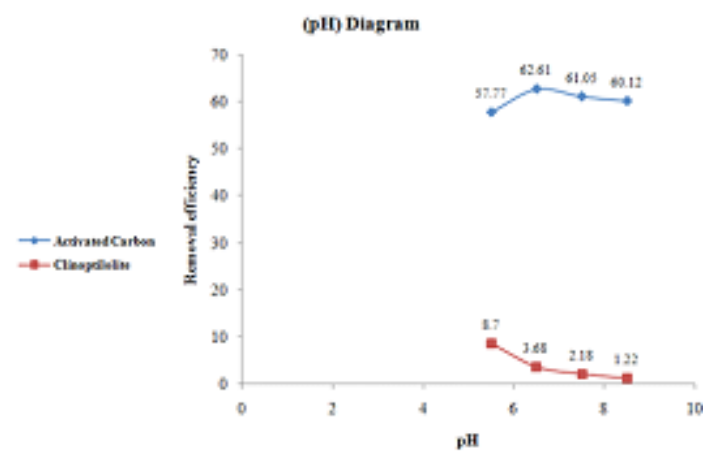

$\left(\mathrm{V}=60 \mathrm{ml}\right.$, Adsorbent dosage $=4$ grams, $\mathrm{T}=20^{\circ} \mathrm{c}$, Contact Time $=60 \mathrm{~min}$, The initial concentration $=100 \mathrm{mg} / \mathrm{lit}$ )

Fig. 3. Effect of pH on the nitrate removal efficiency

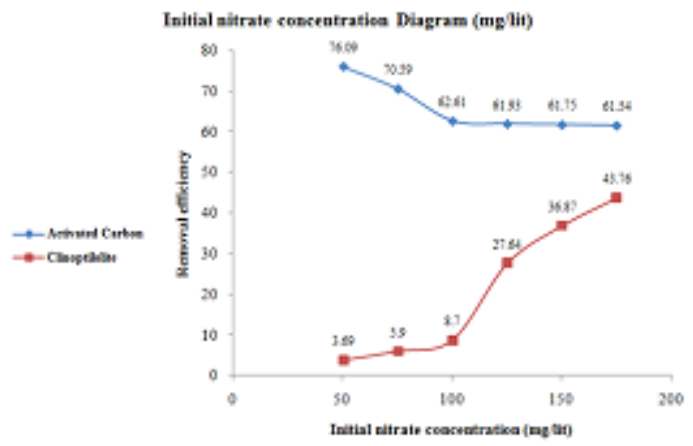

Clinoptilolite conditions: $(\mathrm{V}=60 \mathrm{ml}$, Adsorbent dosage $=4$ grams, $\mathrm{T}=20^{\circ} \mathrm{c}$, Contact Time $=60 \mathrm{~min}, \mathrm{pH}=5.5$ ) Activated carbon conditions: $(\mathrm{V}=60 \mathrm{ml}$, Adsorbent dosage $=4$ grams, $\mathrm{T}=20^{\circ} \mathrm{c}$, Contact Time $=60 \mathrm{~min}$, $\mathrm{pH}=6.5$ )

Fig. 5. The effect of Initial nitrate concentration on the removal rate of nitrate

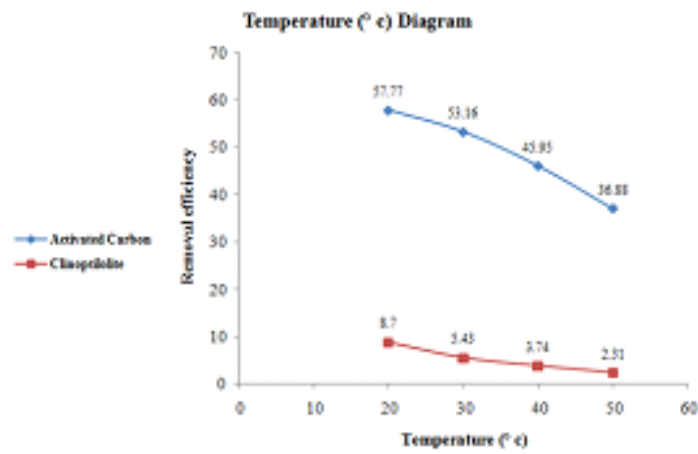

$(\mathrm{V}=60 \mathrm{ml}$, Adsorbent dosage $=4$ grams, Contact time $=$ $60 \mathrm{~min}, \mathrm{pH}=5.5$, The initial concentration=100 mg/lit)

Fig. 2. Effect of temperature on the nitrate removal efficiency

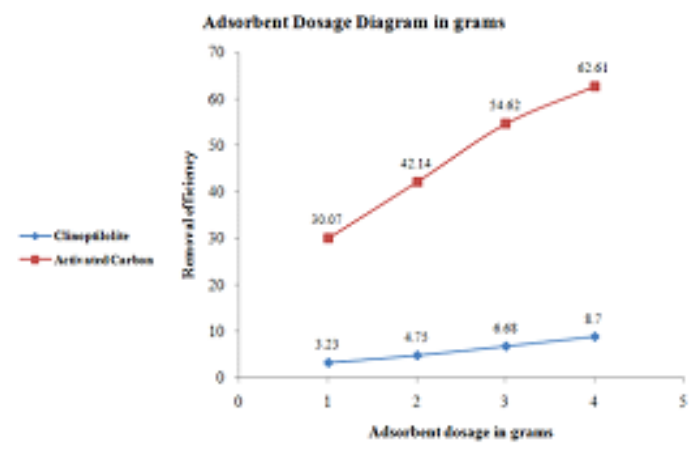

Clinoptilolite conditions: $\left(\mathrm{V}=60 \mathrm{ml}, \mathrm{T}=20^{\circ} \mathrm{c}\right.$, Contact Time $=60 \mathrm{~min}, \mathrm{pH}=5.5$, The initial concentration $=100 \mathrm{mg} / \mathrm{lit}$ ) Activated carbon conditions: $\left(\mathrm{V}=60 \mathrm{ml}, \mathrm{T}=20^{\circ} \mathrm{c}\right.$, Contact Time=60min, $\mathrm{pH}=6.5$, The initial concentration $=100 \mathrm{mg} / \mathrm{lit}$ )

Fig. 4. The effect of adsorbent dosage on the removal rate of nitrate

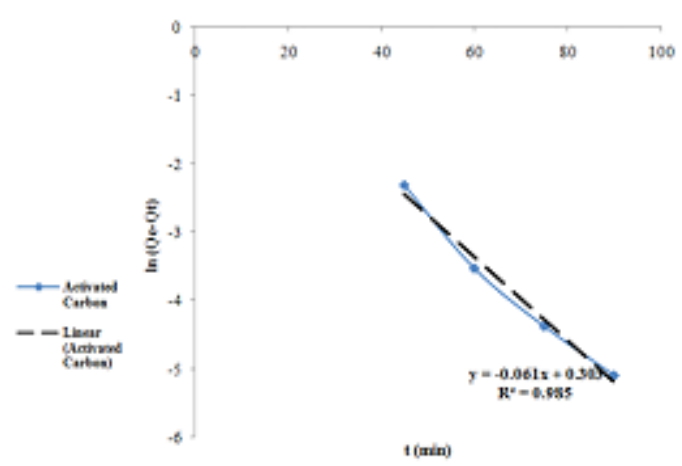

Fig. 6. Activated carbon first order pseudo kinetic model (Lagergren) 
constant factors. At the end of each trial, by determining the optimal values, we investigate the other effects of the various factors.

\section{RESULTS}

\section{Effect of contact time:}

Effect of contact time on nitrate removal efficiency is shown in Figure 1. These results suggest that increased contact time has a positive effect on the efficiency of nitrate removal by two adsorbents. Within first 60 minutes, nitrate adsorption process is fast and since 60 minutes passage, a significant increase is not observed in nitrate due to the saturation of the adsorbent surface of nitrate and adsorption rate reaches equilibrium after 105 minutes. Because after 60 minutes, nitrate adsorption is low and is not economical, optimum contact time is 60 minutes that for activated carbon, we face the removal of

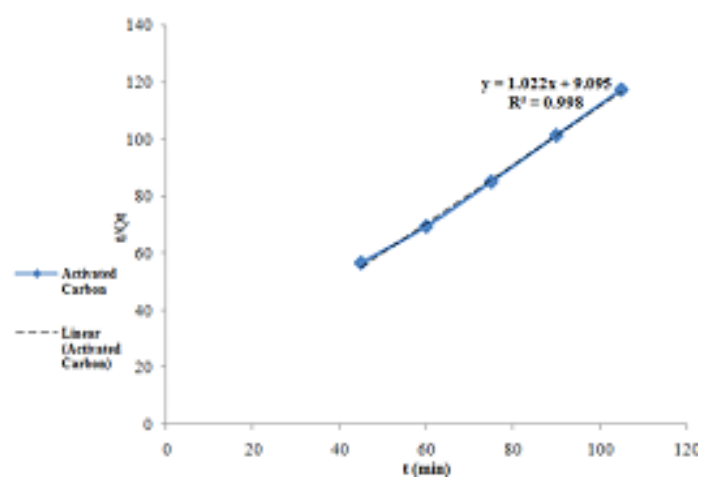

Fig. 7. Activated carbon second order pseudo kinetic model (Ho)

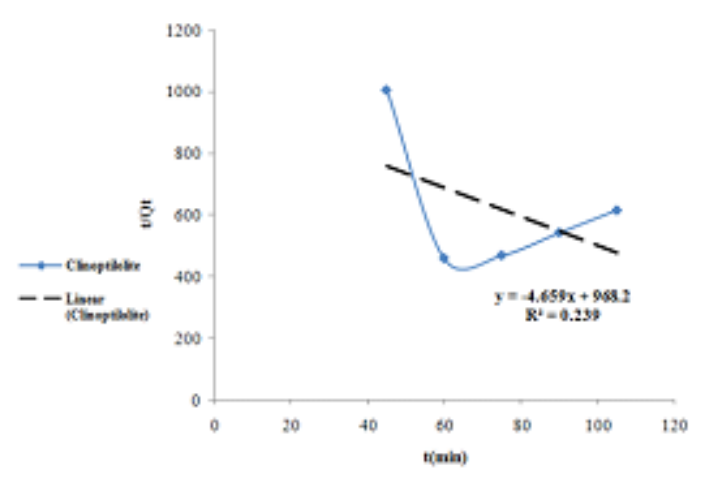

Fig. 9. Clinoptilolite second order pseudo kinetic model (Ho)
57.77 percent and 8.7 percent for clinoptilolite removal.

\section{Effect of Temperature}

Results of effect of temperature on nitrate removal efficiency are shown in Figure 2. The results show that as the temperature increases, the amount of nitrate adsorption in both adsorbents decreases. Optimum temperature for both adsorbents is $20^{\circ} \mathrm{C}$ that for activated carbon, we face the removal of 57.77 percent and 8.7 percent for clinoptilolite removal.

\section{Effect of initial $\mathrm{pH}$}

Initial $\mathrm{pH}$ is selected in the ranges of drinking water. The influence of $\mathrm{pH}$ on efficiency is shown in Figure 3. The data show that for clinoptilolite adsorbent with increasing $\mathrm{pH}$, nitrate adsorption rate decreases. And for activated carbon adsorbent with increasing $\mathrm{pH}$ from 5.5 to 6.5 , nitrate adsorption rises and with increasing $\mathrm{pH}$ from 6.5 to 8.5 , the nitrate adsorption is reduced gradually.

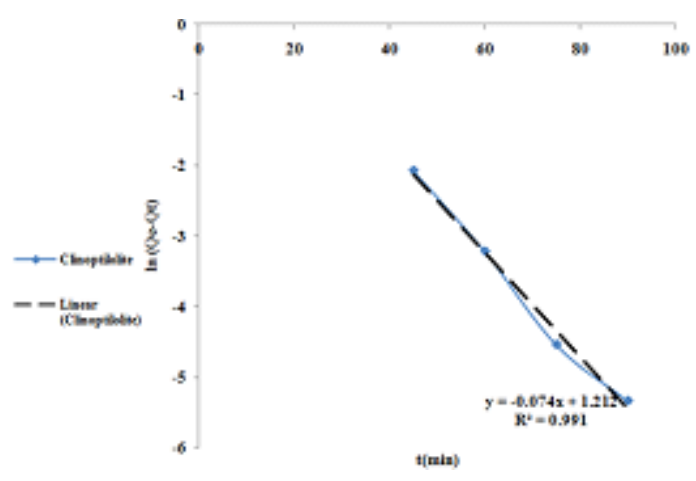

Fig. 8. Clinoptilolite first order pseudo kinetic model (Lagergren)

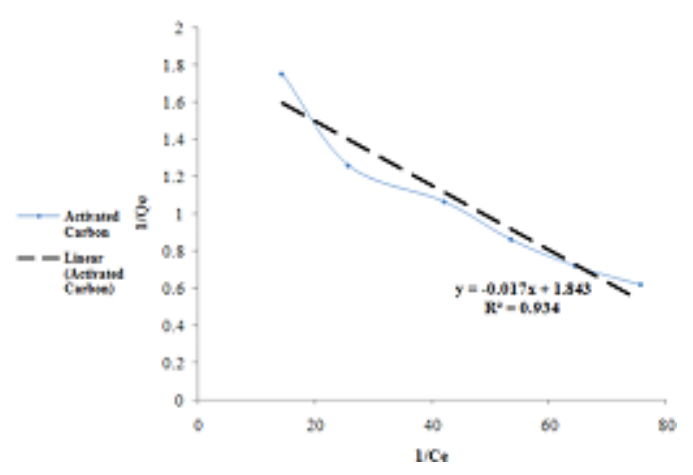

Fig. 10. Langmuir isotherm for nitrate adsorption by activated carbon 
Optimum pH for activated carbon is 6.5 and in this $\mathrm{pH}$, nitrate removal rate is $62.61 \%$ selected $\mathrm{pH}$ for clinoptilolite is 5.5 that in this $\mathrm{pH}$, removal nitrate rate is 8.7 percent.

\section{Effect of adsorbent dosage:}

The results of determining the optimal amount of adsorbent dosage is shown in Figure 4.

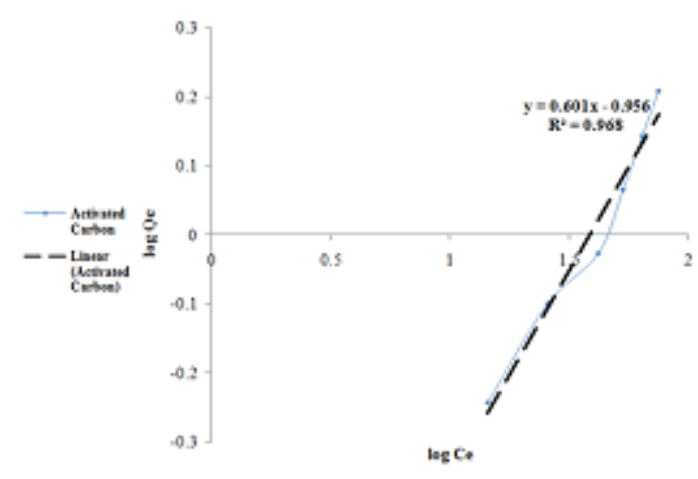

Fig. 11. Freundlich isotherm for nitrate adsorption by activated carbon

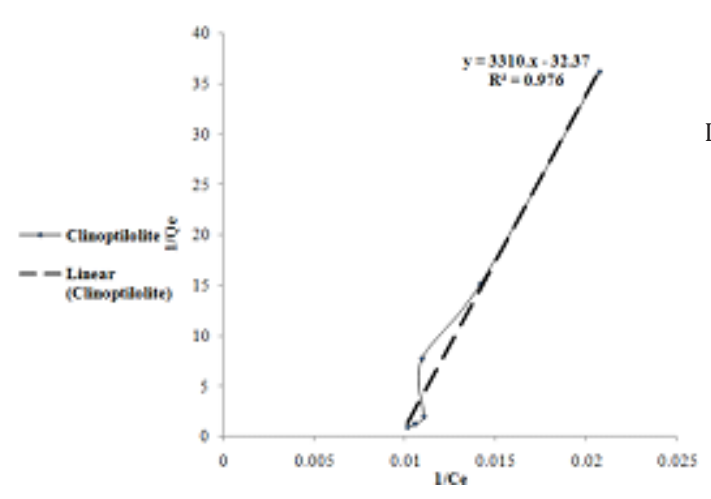

Fig. 12. Langmuir isotherm for nitrate adsorption by Clinoptilolite

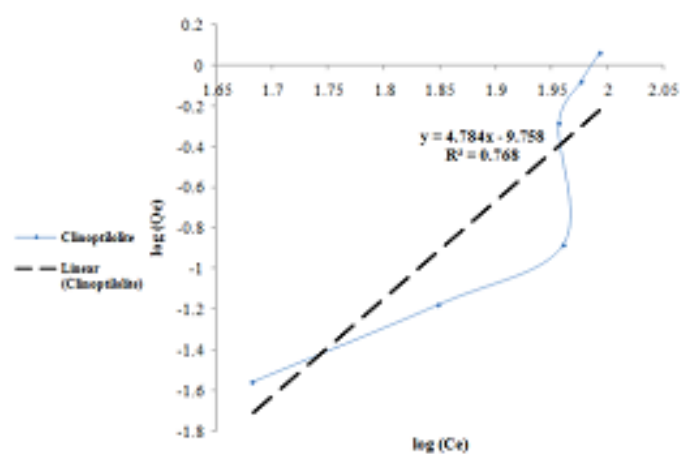

Fig. 13. Freundlich isotherm for nitrate adsorption by Clinoptilolite
As expected, the nitrate removal efficiency decreases by reducing the amount of adsorbent. In the optimum adsorbent dosage of $4 \mathrm{~g}$, for activated carbon, the removal is 62.61 percent and 8.7 percent for Clinoptilolite.

\section{Initial nitrate concentration effect}

The results of Initial nitrate concentration effect of nitrate removal efficiency are shown in Figure 5. The results show that for activated carbon sorbent, by increasing the initial concentration of nitrate, nitrate adsorption is reduced and for the adsorbent Clinoptilolite with increasing initial concentration of nitrate, nitrate adsorption rate increases. These results show that nitrate adsorption by activated carbon is a chemical reaction and nitrate adsorption by Clinoptilolite is a physical reaction.

\section{Adsorption kinetics investigation}

Kinetic models are proposed to clarify the mechanism of absorption and adsorption performance evaluation that depend on the physical and chemical characteristics of the adsorbent and mass transfer process. The kinetic models are examined as follows.

$$
\begin{aligned}
& \operatorname{Ln}\left(\mathrm{q}_{\mathrm{e}}-\mathrm{q}_{\mathrm{t}}\right)=-\mathrm{k}_{1} \mathrm{t}+\mathrm{Ln} \mathrm{q}_{\mathrm{e}} \quad \begin{array}{l}
\text { The first order pseudo } \\
\text { model (Lagergren) }
\end{array} \\
& \left(\frac{\mathrm{t}}{\mathrm{q}_{\mathrm{t}}}\right)=\frac{1}{\mathrm{k}_{2} \mathrm{q}_{\mathrm{e}}{ }^{2}}+\left(\frac{1}{\mathrm{q}_{\mathrm{e}}}\right) t \quad \begin{array}{l}
\text { The second pseudo } \\
\text { model (HO) }
\end{array}
\end{aligned}
$$

In Figures 6, 7, 8 and 9, results of two first and second order pseudo kinetic models for two adsorbents are shown. These results indicate that activated carbon sorbent is most consistent with Ho second order pseudo kinetic model $\left(\mathrm{R}^{2}=0.998\right)$ and clinoptilolite adsorbent is most consistent with Lagergren first order pseudo kinetic model $\left(\mathrm{R}^{2}=0.991\right)$.

Using these results, it showed that nitrate adsorption by activated carbon is a chemical reaction and nitrate adsorption by Clinoptilolite is a physical reaction. In this study, the fixed amounts related to first and second pseudo models are calculated in Tables 6 and 7.

\section{Reviewing adsorption isotherms}

In this paper, two known Langmuir and Freundlich isotherm models are selected to assess the amount of adsorbed nitrate on activated carbon and Clinoptilolite in aqueous solution. Linear form of Langmuir and Freundlich is as follows.

$\begin{array}{ll}\frac{1}{q_{e}}=\frac{1}{C_{e} k_{1} q_{\max }}+\frac{1}{q_{\max }} & \text { Linear form of Langmuir isotherm } \\ \log q_{e}=\log k_{2}+\frac{1}{n} \log C_{e} & \text { Linear form of Freundlich isotherm }\end{array}$ 
Figures 10,11, 12 and 13 show Langmuir and Freundlich isotherms for nitrate removal by activated carbon and Clinoptilolite adsorbents. These results indicate that activated carbon adsorbent best match to Freundlich isotherm $\left(\mathrm{R}^{2}=0.968\right)$ and clinoptilolite adsorbent best match to Langmuir isotherm $\left(\mathrm{R}^{2}=0.976\right)$. In this study, the Langmuir and Freundlich isotherms values and constants are calculated and presented in Tables 8 and 9.

\section{CONCLUSION}

In this study, activated carbon and Clinoptilolite sorbents for the removal of nitrates from water are studied and the effects of contact time, temperature, $\mathrm{pH}$, adsorbent dosage, initial nitrate concentration, adsorption isotherms and adsorption kinetics in the nitrate removal process was determined. The results showed that activated carbon sorbent is much better than Clinoptilolite and has more ability to remove the activated carbon.

The results are as follows:

1) Nitrate removal in both adsorbents by increasing the contact time increases and the most removal was done in the first 60 minutes and then removing rate is decreased. For economic reasons and that the removal rate of nitrate decreased after 60 minutes, optimal contact time of 60 minutes was determined.

2) As expected, as the temperature increases, the amount of nitrate removal by both adsorbent decreases and the optimum temperature for both adsorbent was determined as ${ }^{\circ} \mathrm{c} 20$.

3) $\mathrm{pH}$ reviewed in this study is in the study is in the range of drinking water. The optimum $\mathrm{pH}$ for nitrate removal by activated carbon and Clinoptilolite are 6.5 and 5.5, respectively.

4) As expected, by reducing the dose of adsorbent, the removal of nitrate decreased. Adsorbent dosage $4 \mathrm{~g}$ for both adsorbents was determined as the optimum adsorbent dose.

5) For activated carbon adsorbent with increasing initial concentration of nitrate, nitrate removal rate decreases. It can be concluded that, nitrate removal by activated carbon is a chemical reaction and for Clinoptilolite adsorbent by increasing the initial concentration of nitrate, nitrate removal rate increases and it can be concluded that nitrate removal by Clinoptilolite is a physical reaction.

6) For proving physical or chemical reaction of adsorbed by the adsorbent and nitrate adsorption, adsorption kinetics was studied and the results showed that activated carbon adsorbent follows pseudo-secondorder kinetic model (Ho) which represents the chemical adsorption of nitrate and Clinoptilolite adsorbent follows pseudo-first model (Lagergren) that represents the physical adsorption of nitrate.

7) Nitrate adsorption by activated carbon with a correlation coefficient of $\mathrm{R}^{2}=0.968$ follows the Freundlich isotherm reflecting the adsorbed fit with Freundlich model and multilayer nitrate adsorption on activated carbon and nitrate adsorption by Clinoptilolite with a correlation coefficient $\mathrm{R}^{2}=0.976$ follows the Langmuir isotherm which indicates the adsorbed fit with Langmuir monolayer on Clinoptilolite.

Nitrate removal by activated carbon in optimal conditions, $4 \mathrm{~g}$ adsorbent dosage, contact time of 60 minutes, the temperature of ${ }^{\circ} \mathrm{c} 20, \mathrm{pH}=6.5$ and initial concentration of $100 \mathrm{mg} / \mathrm{lit}$ in $60 \mathrm{ml}$ water and the removal efficiency of 62.61 is achieved. As we observed, activated carbon has the ability to remove nitrates and reach its concentration in drinking water less than the limit. Nitrate removal by Clinoptilolite in optimal conditions, $4 \mathrm{~g}$ adsorbent dosage, contact time of 60 minutes, the temperature of ${ }^{\circ}$ c $20, \mathrm{pH}=5.5$ and initial concentration of 100mg/lit in $60 \mathrm{ml}$ water and the removal efficiency of 8.7 is achieved. As we can see, Clinoptilolite has not ability to remove nitrates and reach its concentration in drinking water less than the limit.

\section{REFERENCES}

1. APHA, WPCF. Standard method for the examination of water and wastewater. 20th ed: Washingon D.C 1999.

2. Avery, A.A. Infantile methemoglobinemia : 
reexamining the role of drinking water nitrates. Environmental Health Perspectives 107, 583586, 1999.

3. Ceval, J., Elsevier (Desalination), “Nitrate removal and water quality improvement with reverse osmosis for Brighton”, Colorado, 1995; 103: $101-111$

4. D.Reynolds,t. unit operation and processes in environmental engineering: sharif university 1995.

5. Eslami,A. Nitrate Removal from Drinking Water Using Modified Natural Clays. water and wastewater journal. 2014; 25(3):127-34.

6. Govindan, K., Elsevier (Journal of Water Process Engineering), "Removal of nitrate ion from water by electrochemical approache”s, 2015; 6: 5863

7. Khani ,A. Comparative study of nitrate removal from aqueous solution using powder activated carbon and carbon nanotubes. 2nd International IUPAC Conference on Green Chemistry. Russia 2008, pp. 14-19.

8. L'hirondel, J. Nitrarte and Man, Toxic, Harmless or Beneficial? CABI Publishing, 2002; 147.

9. Mahmudov, R. Selective adsorption of oxyanions on activated carbon exemplified by Filtrasorb 400 (F400), Separ. Purif. Technol.,doi:10.1016/j.seppur.2010.12.019.

10. Mizuta, K. Removal of nitrate-nitrogen from drinking water using bamboo powder charcoal, Bioresour. Technol. 2004; 95: 255-257; ) .

11. Pudukadu, M.A. Journal Of BioScience And BioEngineering, "Two-Stage Removal of Nitrate from Groundwater using Biological and Chemical Treatments”, 2007; 104(2): 129-134.

12. Strebel, O. Nitrate pollution of groundwater in western Europe, Agric., Ecosyst. Environ. 26 (1989) 189-214

13. Teribal .R.E. Mass- Transfer Operation: Third Edition: McGraw - Hill 1981.

14. http://www.afrazand.com/Zeolite.html

15. https://www.en.wikipedia.org/wiki/Nitrate

16. http://www.isiri.org

17. http://www.sigmaaldrich.com/catalog/product/ sial/c2889?lang=en\&region=IR

18. http://www.water-research.net/index.php/ nitrate 